\title{
Apribojimai ir draudimai už Viešųjų ir privačių interesų derinimo valstybinẻje tarnyboje įstatymo pažeidimus: kai kurie probleminiai aspektai
}

\author{
Virginijus Kanapinskas \\ Mykolo Romerio universitetas \\ Ateities g. 20, LT-08303 Vilnius, Lietuva \\ doi:10.13165/VPA-14-13-4-06
}

Anotacija. Straipsnyje atskleidžiama, kad dabartinis teisinis reguliavimas, nustatantis apribojimus ir draudimus asmenims, pažeidusiems Viešujų ir privačiu interesu derinimo valstybineje tarnyboje istatymo reikalavimus, kai kuriais svarbiais aspektais stokoja konstitucinio pagrindimo, aiškumo ir vidinès darnos. Tai sudaro prielaidas nevienodai aiškinti ir taikyti teisès normas, nustatančias apribojimus ir draudimus už minèto istatymo reikalavimu pažeidimus. Šie teiginiai pagrindžiami analizuojant su tyrimo objektu susijusias teisès normas Lietuvos Respublikos Konstitucinio Teismo oficialiosios konstitucinès doktrinos, Lietuvos vyriausiojo administracinio teismo jurisprudencijos ir Vyriausiosios tarnybinès etikos komisijos veiklos praktikos kontekste.

Reikšminiai žodžiai: apribojimai, asmenys, dirbantys valstybineje tarnyboje, draudimai, privatūs interesai, viešieji interesai.

Keywords: persons in the civil service, private interests, prohibitions, public interests, restrictions.

\section{Ivadas}

Tyrimo problema. Konstituciškai pagrịsta, kad asmenys, dirbantys valstybinejje tarnyboje, jeigu jie nevengia viešųjų ir privačių interesų konfliktų, būtų traukiami atsakomybėn [2], ịskaitant tam tikrų apribojimų ar draudimų jiems taikymą (žr. Konstitucinio Teismo 2004 m. liepos 1 d. nutarimas, 2004 m. gruodžio 13 d. nutarimas) $[16,17]$. Vertinant ne tik formaliuoju, bet ir turininguoju požiūriu, matyti, kad dabartinis teisinis reguliavimas, nustatantis apribojimus ir draudimus 
asmenims, pažeidusiems Viešųjų ir privačių interesų derinimo valstybinėje tarnyboje įstatymo reikalavimus, kai kuriais svarbiais aspektais stokoja konstitucinio pagrindimo, aiškumo ir vidinès darnos. Tai sudaro prielaidas nevienodai aiškinti ir taikyti teisès normas, nustatančias apribojimus ir draudimus už minèto įstatymo reikalavimų pažeidimus.

Temos naujumas ir aktualumas. Asmenų, dirbančių valstybinèje tarnyboje, viešųjų ir privačių interesų derinimas (tiksliau būtų vartoti viešųjų ir privačių interesų konfliktų vengimo arba šių interesų atskyrimo kategoriją) yra teisiniu, politiniu, vadybiniu, visuomeniniu ir kitais požiūriais labai reikšmingas ir specifinis teisinio reguliavimo objektas. Tai akivaizdu ịvertinus ịstatymų leidejo tikslus: 1) užtikrinti, kad priimant sprendimus pirmenybè būtų teikiama viešiesiems interesams; 2) ịtvirtinti priimamų sprendimų nešališkumą; 3) užkirsti kelią korupcijai valstybinëje tarnyboje. Bendras viešojo administravimo etikos problemas analizavo daug Lietuvos mokslininkų: J. Palidauskaitė [3, 4], N. Vasiljevienė [6], Č. Kalenda [1] ir kt., tačiau duomenų apie teisès krypties mokslininkų tyrimus, tiesiogiai susijusius su šio straipsnio tema, nerasta. Todèl šiame straipsnyje dėstomos mintys gali būti ịdomios ir naudingos ne tik teisininkams, viešojo administravimo specialistams, bet ir kiekvienam valstybineje tarnyboje dirbančiam asmeniui.

Tyrimo tikslas - išanalizuoti kai kuriuos probleminius aspektus, susijusius su teisès normų, nustatančiu apribojimus ir draudimus asmenims, pažeidusiems Viešųjų ir privačių interesų derinimo valstybinèje tarnyboje įstatymo reikalavimus, aiškinimu ir taikymu.

Tyrimo objektas - kai kurie probleminiai aspektai, susiję su teisės normų, nustatančių apribojimus ir draudimus už Viešųjų ir privačiu interesų derinimo valstybinejje tarnyboje įstatymo reikalavimų pažeidimus, aiškinimu ir taikymu.

Tyrimo metodika. Dokumentų analizès metodas taikytas siekiant gauti informacijos, kokybiškai tiriant socialinių mokslų srities mokslines publikacijas, įvairius teisès aktus ir kitus teisinès veiklos praktikos dokumentus, susijusius su viešųjų ir privačių interesų konfliktais valstybinejje tarnyboje. Straipsnio autorius yra Vyriausiosios tarnybinès etikos komisijos (toliau - VTEK) narys ir turi didelę profesinès veiklos patirti valstybinès tarnybos srityje, todèl buvo pasitelktas ir stebejimo metodas. Sisteminès analizès metodas taikytas kompleksiškai vertinant teisès normų, nustatančių apribojimus ir draudimus už minèto įstatymo pažeidimus, santykị su Konstitucija, kitais ịstatymais, teisẻkūros principais. Lyginamuoju analizès metodu lyginti ịvairūs atvejai, susiję su tyrimo objektu. Apibendrinimo metodas pasitelktas apibendrinant surinktus ir išanalizuotus tyrimo duomenis, formuluojant išvadas ir pasiūlymus.

\section{Apribojimų ir draudimų už Viešųjų ir privačių interesų derinimo valstybinèje tarnyboje įstatymo pažeidimus samprata}

Seimas $2012 \mathrm{~m}$. birželio 12 d. prièmė Viešųjų ir privačių interesų derinimo valstybineje tarnyboje įstatymo 2, 3, 4, 5, 6, 7, 11, 14, 15, 18, 22 straipsnių pakeiti- 
mo ir papildymo įstatymą Nr. XI-2063 (įsigaliojo $2012 \mathrm{~m}$. birželio 27 d.), kurio 9 straipsniu pakeite šio ịstatymo 15 straipsnị (2008-07-01 redakcija) ir išdèste jị taip:

„1. Valstybineje tarnyboje dirbantys asmenys, teisès aktų nustatyta tvarka pripažinti pažeidusiais šio ịstatymo antrojo skirsnio reikalavimus, vienerius metus nuo pažeidimo paaiškejjimo dienos negali būti skatinami. Valstybinèje tarnyboje dirbantys asmenys, teisès aktų nustatyta tvarka pripažinti pažeidusiais šio įstatymo pirmojo skirsnio 3 straipsnio 6 punkto reikalavimus, vienerius metus nuo pažeidimo paaiškẻjimo dienos negali būti skatinami, priimami, skiriami ar renkami ị aukštesnes pareigas. Valstybinejje tarnyboje dirbantys asmenys, teisès aktų nustatyta tvarka pripažinti pažeidusiais kitus šio įstatymo reikalavimus, vienerius metus nuo pažeidimo paaiškejjimo dienos negali būti skatinami, priimami, skiriami ar renkami i aukštesnes pareigas, o asmenys, atleisti už šio ịstatymo pažeidimą iš pareigų, trejus metus nuo atleidimo iš pareigų dienos negali būti priimami, skiriami ar renkami i pareigas valstybineje tarnyboje.

2. Asmenims, dirbantiems valstybinèje tarnyboje, kituose įstatymuose gali būti nustatyta ir kitų apribojimų ir draudimų, susijusių su šio ịstatymo, Korupcijos prevencijos įstatymo, Valstybės tarnybos ịstatymo, Politikų elgesio kodekso ar kito teisès akto, reglamentuojančio tarnybinès etikos ir elgesio normas, reikalavimų pažeidimais.“ " [13]

Nauja tokio teisinio reguliavimo savybè yra ta, kad minèti apribojimai, draudimai ir jų taikymo pagrindai diferencijuojami ị tris grupes, atsižvelgiant ị padarytus pažeidimus. Pirmoji grupe yra įstatymo antrojo skirsnio reikalavimų, susijusių su privačių interesų deklaravimu, pažeidimas. Valstybinejje tarnyboje dirbantis asmuo vienerius metus nuo tokio pažeidimo paaiškejjimo dienos negali būti skatinamas. Pagal teisines pasekmes tai yra švelniausia poveikio priemonè. Kita grupe yra įstatymo pirmojo skirsnio 3 straipsnio 6 punkte nustatyto reikalavimo nesinaudoti ir neleisti naudotis jokiu valstybės ar savivaldybių valdomu turtu ne tarnybinei veiklai pažeidimas. Valstybineje tarnyboje dirbantis asmuo vienerius metus nuo tokio pažeidimo paaiškejjimo dienos negali būti skatinamas, priimamas, skiriamas ar renkamas ị aukštesnes pareigas. Trečioji grupé yra plačiausia, nes apima visus kitus minèto įstatymo reikalavimų pažeidimus, kuriuos padarę asmenys vienerius metus nuo pažeidimo paaiškèjimo dienos negali būti skatinami, priimami, skiriami ar renkami ị aukštesnes pareigas, o asmenys, atleisti už šio įstatymo pažeidimą iš pareigų, trejus metus nuo atleidimo iš pareigų dienos negali būti priimami, skiriami ar renkami i pareigas valstybinèje tarnyboje.

Autoriaus nuomone, toks teisinis reguliavimas turi nemažai trūkumų. Pirma, nèra aiškūs minètų pažeidimų bei atitinkamų apribojimų ir draudimų juos padariusiems asmenims klasifikavimo kriterijai. Antras aspektas, keliantis tokio teisinio reguliavimo aiškinimo ir taikymo problemas, yra įstatyme vartojamos asmenų, dirbančių valstybinejje tarnyboje, kuriems gali būti taikomi minèti apribojimai ir draudimai, sąvokos apimtis ir neapibréžtumas. Minèto ịstatymo 2 straipsnio 2 dalyje nustatyta, kad: „Asmenys, dirbantys valstybinëje tarnyboje - valstybės politikai, 
valstybės pareigūnai, valstybės tarnautojai, teisėjai, žvalgybos pareigūnai, profesinès karo tarnybos karininkai, asmenys, dirbantys valstybės ir savivaldybių imonèse, biudžetinèse įstaigose ir turintys administravimo ịgaliojimus, asmenys, dirbantys viešosiose įstaigose ir asociacijose, kurios gauna lèšų iš Lietuvos valstybès ar savivaldybių biudžetų ir fondų, ir turintys administravimo igaliojimus, Lietuvos banko darbuotojai, turintys viešojo administravimo ịgaliojimus (atliekantys finansu rinkos priežiūros, vartotojų ir finansų rinkos dalyvių ginčų nagrinėjimo ne teisme funkcijas ir kitas viešojo administravimo funkcijas), akcinių bendrovių ir uždarųjų akcinių bendrovių, kurių akcijos, suteikiančios daugiau kaip 1/2 balsų visuotiniame akcininkų susirinkime, nuosavybės teise priklauso valstybei ar savivaldybei, vadovai ir vadovų pavaduotojai, taip pat kiti asmenys, turintys viešojo administravimo igaliojimus.“ [13] Iš šios sąvokos turinio ir apimties matyti, kad ji apima labai platų subjektų ratą, t. y. ne tik valstybės politikus, valstybès pareigūnus, valstybès tarnautojus, teisèjus, bet ir kitus asmenis, dirbančius valstybės ir savivaldybių įmonèse, biudžetinèse įstaigose, kurie turi administravimo igaliojimus, taip pat asmenis, turinčius administravimo igaliojimus ir dirbančius viešosiose ịstaigose ir asociacijose, kurios gauna léšų iš Lietuvos valstybės ar savivaldybių biudžetų ir fondų, ir kt. İvertinus tai, kyla pagrịstas klausimas, kaip praktikoje būtų taikomi minèti apribojimai ir draudimai, jei, tarkime, asmuo „A“ teisès aktų nustatyta tvarka būtų pripažintas pažeidusiu Viešųų ir privačių interesų derinimo valstybinėje tarnyboje įstatymo reikalavimus ir nepraejjus vienerių metų terminui pretenduotų ị kitas skiriamas ar renkamas pareigas valstybinejje tarnyboje, kai dèl pareigų ịvairovès, priklausomybès skirtingoms valstybinès valdžios šakoms ar kitų objektyvių priežasčių sunku ar net neįmanoma nustatyti, kurios iš šių pareigų aukštesnès. VTEK veiklos praktikos kontekste tikslinga išanalizuoti keletą atvejų, kai iškilo poreikis taikyti minètus apribojimus ir draudimus.

\section{Kai kurie apribojimų ir draudimų už Viešųjų ir privačių interesų derinimo valstybinėje tarnyboje įstatymo pažeidimus taikymo atvejai}

1 atvejis. VTEK $2008 \mathrm{~m}$. vasario 14 d. sprendimu Nr. KS-8 [23] pripažino, kad Vilniaus miesto savivaldybės tarybos narys A. Štaras pažeidė Viešųjų ir privačių interesų derinimo valstybineje tarnyboje įstatymo 3 straipsnio 6 punkto nuostatas. Šio pažeidimo padarymo ir paaiškejjimo metu galiojusio Viešųjų ir privačių interesų derinimo valstybinejje tarnyboje įstatymo 15 straipsnyje (2003-11-03 redakcija) buvo nustatyta, kad: „Valstybinejje tarnyboje dirbantys asmenys, teisès aktų nustatyta tvarka pripažinti pažeidusiais šio įstatymo reikalavimus, vienus metus negali būti skatinami, skiriami ị aukštesnes pareigas, o atleisti iš valstybinès tarnybos už šio įstatymo pažeidimus trejus metus nuo atleidimo negali būti priimami ị valstybinę tarnybą." [13] 2008 metų gruodžio mėnesị (nepraejjus vieneriems metams nuo minèto pažeidimo paaiškejjimo dienos) A. Štaras priimtas ị Susisiekimo ministerijos viceministro pareigas ir èjo šias pareigas iki 2012 m. gruodžio 13 d. 
2 atvejis. Vilniaus miesto savivaldybès tarybos etikos komisija $2012 \mathrm{~m}$. kovo 12 d. sprendimu Nr. 9-37-(1.1.39-T1) [28] konstatavo, kad šios savivaldybės tarybos narys A. Zaremba pažeidė Viešųjų ir privačių interesų derinimo valstybinèje tarnyboje ịstatymo 11 straipsnio 1 ir 2 dalies nuostatas. 2013 metų sausio ménesi A. Zaremba priimtas ị Energetikos ministerijos viceministro pareigas. $2013 \mathrm{~m}$. sausio 2 d. VTEK sekretoriato vadovas T. Čaplinskas pateikè asmeninę nuomonę, kad A. Zaremba gali eiti viceministro pareigas, nes draudimas eiti aukštesnes pareigas galioja tik toje pačioje institucijoje, t. y. Vilniaus miesto savivaldybės taryboje [31], tačiau $2013 \mathrm{~m}$. sausio $23 \mathrm{~d}$. VTEK, vadovaudamasi VTEK ịstatymo 18 straipsnio 5 punktu, nutarẻ kreiptis ị Energetikos ministrą, siūlydama atleisti A. Zarembą iš Energetikos ministerijos viceministro pareigų, nes jo priemimas nesuderinamas su Viešųjų ir privačių interesų derinimo valstybinèje tarnyboje įstatymo 15 straipsnyje nustatytais apribojimais ir draudimais [30]. $2013 \mathrm{~m}$. vasario $11 \mathrm{~d}$. A. Zaremba atleistas iš Energetikos ministerijos viceministro pareigų.

3 atvejis. VTEK 2009 m. gruodžio 16 d. sprendimu Nr. KS-103 [24] konstatavo, kad Tauragès rajono savivaldybės mero pavaduotojas Pranas Petrošius nevykde Viešujų ir privačių interesų derinimo įstatymo 3 straipsnio 2 punkto ir pažeide 11 straipsnio 1 bei 2 dalies, 7 straipsnio 2 dalies nuostatas. Tauragès rajono savivaldybès taryba $2010 \mathrm{~m}$. sausio $22 \mathrm{~d}$. sprendimu Nr. 1-1379 [27] nusprende išrinkti Tauragès rajono savivaldybės tarybos narị P. Petrošių Tauragès rajono savivaldybės tarybos meru savivaldybès tarybos iggaliojimų laikui. VTEK $2010 \mathrm{~m}$. sausio $25 \mathrm{~d}$. informavo apie Tauragès rajono savivaldybès tarybos mero pavaduotojo P. Petrošiaus padarytą pažeidimą ir apie tai, kad jis vienus metus nuo pažeidimo paaiškẻjimo dienos negali būti skatinamas, skiriamas ị aukštesnes pareigas. Vyriausybès atstovas Tauragès apskrityje $2010 \mathrm{~m}$. sausio 29 d. teikimu Nr. 6-1 [29] pasiūlè artimiausiame savivaldybès tarybos posèdyje svarstyti Tauragès rajono savivaldybès tarybos 2010 m. sausio 22 d. sprendimo Nr. 1-1407 „Dèl Tauragès rajono savivaldybės mero išrinkimo" panaikinimo klausimą, tačiau jo vykdymą atidèjo, nes Lietuvos vyriausiajame administraciniame teisme (toliau - LVAT) vyko teisminis ginčas dèl VTEK 2009 m. gruodžio 16 d. sprendimo Nr. KS-103 teisètumo. LVAT 2012 m. sausio 12 d. nutartimi administracinėje byloje Nr. I-1094-624/2010 [22] nusprendè P. Petrošiaus apeliacinị skundą atmesti ir pripažino, kad P. Petrošius padare minètą pažeidimą. Šie pavyzdžiai patvirtina, kad teisinio reguliavimo ydos sudaro prielaidas nevienodai aiškinti minėtus apribojimus ir draudimus nustatančių teisės normų turinị, dviprasmiškai suvokti jų taikymo ribas. Pirmoji ir antroji situacijos buvo iš esmès panašios, tačiau jų vertinimas skirtingas. Trečioji situacija išsiskiria tuo, kad pripažintas pažeidusiu minètą ịstatymą asmuo nepraejjus vienerių metų terminui buvo ne priimtas, o išrinktas ị aukštesnes mero pareigas. Asmens teisẻs būti išrinktam ị aukštesnes pareigas apribojimas yra specifinis, todèl tikslinga ši apribojimą išanalizuoti išsamiau. 


\section{Asmens teisès būti išrinktam ị aukštesnes pareigas apribojimas \\ Viešųjų ir privačių interesų derinimo valstybinėje tarnyboje istatymo pažeidimo kontekste: kai kurie probleminiai aspektai}

Konstitucijos 34 straipsnio 2 dalyje ịtvirtinta teisè būti išrinktam reiškia, kad įstatymų leidejas pagal Konstituciją turi įgaliojimus rinkimų įstatymuose nustatyti tokius reikalavimus (sąlygas) renkamiems asmenims, kurie yra konstituciškai pagrịsti (pvz., Konstitucinio Teismo

2004 m. gegužès 25 d. nutarimas) [15]. Pažymėtina, kad teisè iškelti savo kandidatūrą rinkimuose yra ịtvirtinta Europos žmogaus teisių ir pagrindinių laisvių apsaugos konvencijos (toliau - Konvencija) Pirmojo protokolo 3 straipsnyje [8]. Be abejo, ši teisè nèra absoliuti, jai gali būti taikomi apribojimai. Šioje srityje valstybės turi plačią, tačiau ne visą apimančią diskrecijos laisvę. Mokslinejje literatūroje [5] teigiama, kad valstybès Konvencijos dalyvès negali apriboti teisès būti išrinktam taip, kad pakenktų šios teisès esmei ir dèl to ji netektų savo veiksmingumo, apribojimai turi būti nustatyti siekiant teisèto tikslo, pritaikytos priemonès turi būti proporcingos. Konstitucinis Teismas savo oficialiojoje konstitucineje doktrinoje taip pat yra pasisakęs, kad ịstatyme numatytos priemonès turi atitikti teisètus ir visuomenei svarbius tikslus, kad šios priemonès turi būti būtinos minètiems tikslams pasiekti ir neturi varžyti asmens teisių ir laisvių akivaizdžiai labiau negu reikia šiems tikslams pasiekti (pvz., Konstitucinio Teismo 2009 m. gruodžio 11 d. nutarimas) [19].

Šiuo aspektu pažymètina, kad apribojimai rinkti minètą įstatymą pažeidusius asmenis i kai kurias aukštas pareigas valstybineje tarnyboje stokoja konstitucinio pagrindimo, pvz., visi reikalavimai ir apribojimai kandidatams i Seimo narius, taip pat ir i Respublikos Prezidentus, nustatyti Konstitucijoje (56, 78, 79 straipsniai) [7]. Konstitucijos 56 straipsnio 2 dalyje nustatyta, kad: „Seimo nariais negali būti renkami asmenys, nebaigę atlikti bausmès pagal teismo paskirtą nuosprendị, taip pat asmenys, teismo pripažinti neveiksniais.“ [7] Tokie pat teisės būti išrinktam apribojimai išdèstyti Seimo rinkimų ịstatymo 2 straipsnyje, kurio 6 dalyje aiškiai nustatyta, kad: „Kiti tiesioginiai arba netiesioginiai Lietuvos Respublikos piliečių rinkimų teisès apribojimai - dèl kilmès, politinių pažiūrų, socialinès ir turtinès padèties, nacionalinès priklausomybės, lyties, išsilavinimo, kalbos, santykio su religija, užsièmimo rūšies ir pobūdžio - draudžiami.“ [12] Nagrinėjamos problemos kontekste pažymėtina ir tai, jog konstitucinis teisinès valstybès principas reikalauja, kad įstatymuose ir kituose teisès aktuose ịtvirtintas teisinis reguliavimas turi būti aiškus, darnus, suprantamas, neprieštaringas, teisės aktų formuluotès tikslios (Konstitucinio Teismo 2009 m. rugsejjo $2 \mathrm{~d}$. nutarimas ir kt.) [18]. Pagal konstitucinị teisinès valstybės principą teisékūros subjektai teisès aktus gali leisti tik neviršydami savo ịgaliojimų, turi būti užtikrinami teisès sistemos nuoseklumas ir vidinè darna, teisès aktuose neturi būti nuostatų, vienu metu skirtingai reguliuojančių tuos pačius visuomeninius santykius, turi būti paisoma teisès aktų hierarchijos, dèl kurios draudžiama žemesnès galios teisès aktais nustatyti tokị 
reguliavimą, kuris konkuruotų su nustatytuoju aukštesnès galios teisės aktais arba jị paneigtų. Vienas esminių konstitucinio teisinès valstybès principo elementų yra reikalavimas netaikyti teisės akto, prieštaraujančio aukštesnès galios teisės aktui (pvz., Konstitucinio Teismo 2012 m. rugsejjo 5 d. nutarimas ir kt.) [25]. Atsižvelgiant ị šiuos konstitucinius teisèkūros standartus, darytina išvada, kad papildomų apribojimų nustatymas kandidatams ị Seimo narius ir Respublikos Prezidentus žemesnio lygmens teisès aktais galimai prieštarauja Konstitucijai. Be to, Viešųjų ir privačių interesų derinimo valstybinèje tarnyboje ịstatyme nustatytas apribojimas eiti aukštesnes renkamas pareigas nèra suderintas su atitinkamais rinkimų įstatymais (Lietuvos Respublikos Seimo rinkimų įstatymu, Lietuvos Respublikos Prezidento rinkimų ịstatymu, Lietuvos Respublikos rinkimų i Europos Parlamentą įstatymu, Lietuvos Respublikos savivaldybių tarybų rinkimų ịstatymu) [9, 10, 11, 12], kuriuose nustatyti reikalavimai kandidatams ị Seimo narius, Respublikos Prezidentus, Europos Parlamento narius ir savivaldybės tarybos narius.

Rinkimų teisès apribojimų kontekste paminètina, kad VTEK $2012 \mathrm{~m}$. vasario 21 d. sprendimu Nr. KS-13 [26] pripažino, kad Raseinių rajono savivaldybės meras Remigijus Ačas pažeidè Viešųjų ir privačių interesų derinimo valstybinèje tarnyboje ịstatymo 3 straipsnio 2 dalies, 11 straipsnio 1, 2 dalių ir 13 straipsnio 1 dalies nuostatas, tačiau $2012 \mathrm{~m}$. lapkričio 16 d. jis pradejo eiti aukštesnes Seimo nario pareigas. Šis ir kiti panašūs atvejai (pvz., VTEK 2011 m. lapkričio 15 d. sprendimas Nr. KS-69 [25] ir pažeidimą padariusio asmens dalyvavimas 2012 metų Seimo rinkimuose) rodo, kad apribojimas būti išrinktam ị aukštesnes pareigas neveikia visa apimtimi.

Kita vertus, pažymètina, kad įstatymų leidejjas, užtikrindamas Konstitucijos 3 straipsnio 1 dalyje ịtvirtintą piliečių teisę dalyvauti valdant savo šalị per demokratiškai išrinktus atstovus, turi sudaryti prielaidas atspindèti rinkèjų valią, užtikrinti rinkimų proceso skaidrumą, pasyviąją rinkimų teisę igyvendinančių subjektų sąžiningą konkurenciją ir rinkẻjams reikšmingos informacijos apie juos viešumą (žr. Konstitucinio Teismo 2011 m. lapkričio 17 d. nutarimas ir kt.) [20]. Autoriaus nuomone, informacija, kad kandidatas yra pažeidęs Viešųjų ir privačių interesų derinimo valstybinejje tarnyboje ịstatymą, yra svarbi rinkejjams, apsisprendžiant dèl kandidato tinkamumo renkamoms pareigoms, nes suteikia galimybę sužinoti apie svarbius jo gyvenimo faktus, galinčius turèti reikšmès atstovaujant rinkejjų interesams ir tvarkant viešuosius reikalus. Ivertinus tai svarstytina galimybe rinkimų įstatymuose nustatyti kandidatams ị Seimo narius, Respublikos Prezidentus, Europos Parlamento narius ir savivaldybės tarybos narius pareigą kandidato anketoje pateikti informaciją apie Viešųjų ir privačių interesų derinimo valstybinėje tarnyboje įstatymo pažeidimus, jeigu nuo jų paaiškejjimo dienos nepraejo daugiau kaip vieneri metai, ir teisines pasekmes už tokios pareigos nevykdymą, pvz., išbraukimą iš kandidatų sąrašų. Igyvendinus ši pasiūlymą visuomenei būtų sudaryta reali galimybė apsispręsti, ar asmenys, supainioję viešuosius ir privačius interesus, gali eiti svarbias ir atsakingas renkamas pareigas valstybinèje tarnyboje. 


\section{Išvados}

1. Apribojimai ir draudimai už Viešųjų ir privačių interesų derinimo valstybinejje tarnyboje ịstatymo reikalavimų pažeidimus ir jų taikymo pagrindai diferencijuojami ị kelias grupes, tačiau ši klasifikacija nustatyta neatsižvelgiant ị pareigu valstybinèje tarnyboje įvairovę, specifiką, priklausomybę skirtingoms valstybės bei vietos valdžios šakoms ir kitus objektyvius kriterijus. Šios teisinio reguliavimo ydos sudaro prielaidas nevienodai aiškinti minètus apribojimus ir draudimus nustatančių teisės normų turinį, dviprasmiškai suvokti jų taikymo ribas.

2. Asmens teisès būti išrinktam ị aukštesnes pareigas (pvz., teisè būti išrinktam ị Seimo nario ar Respublikos Prezidento pareigas ir pan.) apribojimas nesuderintas su Konstitucija (58, 78 ir 79 straipsniai) ir atitinkamais rinkimu įstatymais. Ivertinus tai svarstytina galimybe atitinkamuose rinkimu įstatymuose nustatyti kandidatams ị Seimo narius, Respublikos Prezidentus, Europos Parlamento narius ir savivaldybės tarybos narius pareigą kandidato anketoje pateikti informaciją apie Lietuvos Respublikos viešujų ir privačių interesų derinimo valstybinejje tarnyboje ìstatymo pažeidimus, jeigu nuo jų paaiškejjimo dienos nepraejo daugiau kaip vieneri metai, ir teisines pasekmes už tokios pareigos nevykdymą, pvz., išbraukimą iš kandidatų sąrašų. Igyvendinus šį pasiūlymą visuomenei būtų sudaryta reali galimybe apsispręsti, ar asmenys, supainioję viešuosius ir privačius interesus, gali eiti svarbias ir atsakingas renkamas pareigas valstybinejje tarnyboje.

\section{Literatūra}

1. Kalenda Č. Taikomoji etika: iškilimas ir ypatybės Lietuvoje. Filosofija. Sociologija. 2009. T. 20, Nr. 1, 55-62.

2. Kanapinskas V. Administracinė ir tarnybinè (drausminè) atsakomybė už viešųjų ir privačių interesų derinimo valstybès tarnyboje pažeidimus: kai kurie probleminiai aspektai. Jurisprudencija. 2014, 21(3), 784-802.

3. Palidauskaitė J. Interesų konflikto reguliavimo praktika Lietuvoje: balansuojant ant privačiojo ir viešojo intereso ribos. Politologija. 2010, Nr. 1(57), 3-39.

4. Palidauskaitè J. Viešojo administravimo etika. Vadovèlis. Kaunas: Technologija. 2003.

5. Pukanasytė I. Kai kurie teisés ị laisvus rinkimus interpretavimo Europos Žmogaus Teisių Teismo jurisprudencijoje aspektai. Jurisprudencija. 2009, 1(115), 168-172.

6. Vasiljevienè N. Organizacijų etika: institucinès etikos vadybos sistemos. Vilnius: Vilniaus universitetas, 2006.

7. Lietuvos Respublikos Konstitucija. Valstybės žinios. 1992, Nr. 33-1014.

8. Europos žmogaus teisių ir pagrindinių laisvių apsaugos konvencija. Valstybės žinios. 1995. Nr. 40-987; Europos žmogaus teisių ir pagrindinių laisvių apsaugos konvencija, iš dalies pakeista protokolu Nr. 11, su papildomais protokolais Nr. 1, 4, 6 ir 7. Valstybès žinios. 2000, Nr. 96-3016; Europos žmogaus teisių ir pagrindinių laisvių apsaugos konvencija, iš dalies pakeista protokolais Nr. 11 ir Nr. 14. Valstybès žinios. 2011, Nr. 156-7390. 
9. Lietuvos Respublikos Prezidento rinkimų įstatymas. Valstybės žinios. 1993, Nr. 2-29; 2013, Nr. 120-6055.

10. Lietuvos Respublikos rinkimų ì Europos Parlamentą įstatymas. Valstybès žinios. 2003, Nr. 115-5192; 2013, Nr. 121-6116.

11. Lietuvos Respublikos savivaldybių tarybų rinkimų įstatymas. Valstybès žinios. 1994, Nr. 53-996; 1994, Nr. 53-996.

12. Lietuvos Respublikos Seimo rinkimų ịstatymas. Valstybės žinios. 1992, Nr. 22-635; 2000, Nr. 59-1760.

13. Lietuvos Respublikos viešųjų ir privačių interesų derinimo valstybinèje tarnyboje įstatymas. Valstybės žinios. 1997, Nr. 67-1659; 2000, Nr. 18-431.

14. Lietuvos Respublikos vyriausiosios tarnybinès etikos komisijos įstatymas. Valstybès Žinios. 2008, Nr. 81-3176.

15. Lietuvos Respublikos Konstitucinio Teismo 2004 m. gegužès 25 d. nutarimas „Dèl Lietuvos Respublikos Prezidento rinkimų įstatymo 11 straipsnio (2004 m. gegužès 4 d. redakcija) ir 2 straipsnio 2 dalies (2004 m. gegužès 4 d. redakcija) atitikties Lietuvos Respublikos Konstitucijai“. Valstybės žinios. 2004, Nr. 85-3094.

16. Lietuvos Respublikos Konstitucinio Teismo 2004 m. liepos 1 d. nutarimas „Dèl Lietuvos Respublikos Seimo statuto (1998 m. gruodžio 22 d. redakcija) 15 straipsnio 4 dalies atitikties Lietuvos Respublikos Konstitucijai“. Valstybės žinios. 2004, Nr. 105-3894.

17. Lietuvos Respublikos Konstitucinio Teismo 2004 m. gruodžio 13 d. nutarimas „Dèl kai kurių teisès aktų, kuriais reguliuojami valstybės tarnybos ir su ja susiję santykiai, atitikties Lietuvos Respublikos Konstitucijai ir įstatymams“. Valstybės žinios. 2004, Nr. 181-6708.

18. Lietuvos Respublikos Konstitucinio Teismo 2009 m. rugsèjo 2 d. nutarimas „Dèl Lietuvos Respublikos valstybinių socialinio draudimo pensijų įstatymo 30 straipsnio (2005 m. gegužès 19 d. redakcija), 32 straipsnio 4 dalies $(2005 \mathrm{~m}$. gegužès $19 \mathrm{~d}$. redakcija) atitikties Lietuvos Respublikos Konstitucijai“. Valstybės žinios. 2009. Nr. 106-4434.

19. Lietuvos Respublikos Konstitucinio Teismo 2009 m. gruodžio 11 d. nutarimas „Dèl Lietuvos Respublikos valstybès tarnybos įstatymo 23 straipsnio 2 dalies $(2002 \mathrm{~m}$. balandžio 23 d., 2007 m. birželio 7 d. redakcijos) atitikties Lietuvos Respublikos Konstitucijai“. Valstybès žinios. 2009, Nr. 148-6632.

20. Lietuvos Respublikos Konstitucinio Teismo 2011 m. lapkričio 17 d. nutarimas „Dèl Lietuvos Respublikos savivaldybių tarybų rinkimų ịstatymo $(2010 \mathrm{~m}$. birželio $30 \mathrm{~d}$. redakcija) 89 straipsnio 1 dalies, 90 straipsnio 1 dalies atitikties Lietuvos Respublikos Konstitucijai“. Valstybės žinios. 2011, Nr. 141-6634.

21. Lietuvos Respublikos Konstitucinio Teismo 2012 m. rugsėjo 5 d. nutarimas „Dèl Lietuvos Respublikos Seimo rinkimų i̦statymo 2 straipsnio 5 dalies $(2012 \mathrm{~m}$. kovo 22 d. redakcija) atitikties Lietuvos Respublikos Konstitucijai“. Valstybės žinios, 2012, Nr. 105-5330.

22. Lietuvos vyriausiojo administracinio teismo $2012 \mathrm{~m}$. sausio $12 \mathrm{~d}$. nutartis administracinejje byloje Nr. I-1094-624/2010. http://www.eteismai.lt/byla/207422077261344/I1094-624/2010?word=tarnybin\% C4\%97 [2014-06-12]. 
23. Vyriausiosios tarnybinès etikos komisijos $2008 \mathrm{~m}$. vasario $14 \mathrm{~d}$. sprendimas $\mathrm{Nr}$. KS-8 „Dèl Arūno Štaro“. http://www.vtek.lt/sprendimai/wordfile.php?id=652 [2014-01-12].

24. Vyriausiosios tarnybinès etikos komisijos $2009 \mathrm{~m}$. gruodžio $16 \mathrm{~d}$. sprendimas Nr. KS-103 „Dèl Prano Petrošiaus“. http://www.vtek.lt/sprendimai/wordfile.php?id= 897 [2014-01-12].

25. Vyriausiosios tarnybinès etikos komisijos $2011 \mathrm{~m}$. lapkričio 15 d. sprendimas Nr. KS69 „Dèl Artūro Zuoko“. http://www.vtek.lt/sprendimai/wordfile.php?id=1110 [201401-12].

26. Vyriausiosios tarnybinès etikos komisijos $2012 \mathrm{~m}$. vasario $21 \mathrm{~d}$. sprendimas Nr. KS13 ,Dèl Remigijaus Ačo“. http://www.vtek.lt/sprendimai/wordfile.php?id=1146 [201401-12].

27. Tauragès rajono savivaldybès tarybos $2010 \mathrm{~m}$. sausio $22 \mathrm{~d}$. sprendimas Nr. 1-1379 „Dèl Tauragès rajono savivaldybès mero išrinkimo“. http://www.infolex.lt/Taurage/ Default.aspx?Id=3\&DocId=207 [2014-01-12].

28. Vilniaus miesto savivaldybės tarybos etikos komisijos $2012 \mathrm{~m}$. kovo $12 \mathrm{~d}$. sprendimas Nr. 9-37-(1.1.39-T1) „Dèl galimo Tarybos narių Kęstučio Nėniaus ir Algimanto Zarembos viešųjų ir privačių interesų supainiojimo“. http://www.vtek.lt/vtek/index. php?option=com_content $\&$ view $=$ article $\&$ id=1067:2012-03-12-vilniaus-miestosavivaldybs-etikos-komisijos-sprendimas-dl-k-nniaus-ir-a-zarembos-\&catid=10 [2014-01-12].

29. Vyriausybės atstovo Tauragės apskrityje 2010 m. sausio 29 d. teikimas Nr. 6-1 „Dèl Tauragès rajono savivaldybès tarybos $2010 \mathrm{~m}$. sausio $22 \mathrm{~d}$. sprendimo Nr. 1-1407 „Dèl Tauragès rajono savivaldybės mero išrinkimo“. http://vyr-atstovai.lrv.lt/taurage/ index.php?n=267\&l=LT [2014-06-12].

30. Vyriausiosios tarnybinès etikos komisijos $2013 \mathrm{~m}$. sausio 23 d. raštas Nr. S-132-(2.5) Lietuvos Respublikos Seimo parlamentinei grupei „Už Lietuvą be korupcijos“ „Dèl Viešųjų ir privačių interesų derinimo valstybinèje tarnyboje įstatymo nuostatų“. http://www.vtek.lt/vtek/images/vtek/Dokumentai/Titulinio_straipsniai/Seimo_ parlamentinei_grupei.pdf [2014-01-12].

31. http://www.delfi.lt/news/daily/lithuania/vtek-azaremba-negali-buti-aukstinamasvilniaus-taryboje-bet-viceministru-dirbti-gali.d?id=60338987 [2014-01-12].

\section{Virginijus Kanapinskas}

\section{Restrictions and Prohibitions for Violations of Law on the Adjustment of Public and Private Interests in the Civil Service: Some Problematic Aspects}

\section{Summary}

The aim of this article is to analyse restrictions and prohibitions for violations of Law on the Adjustment of Public and Private Interests in the Civil Service. The article reveals that the current legal regulation imposing restrictions and prohibitions on persons who violate Law on the Adjustment of Public and Private Interests in the Civil Service in some important aspects is not constitutionally based, uncertain and unsustainable. It is shown that the regulatory failures preconditions differently interpret and apply the law norms defining the restrictions and prohibitions for violations of the requirements of the mentioned law. This argument is 
supported by the analysis of the said law norms in the context of the Constitutional Court of the Republic of Lithuania official constitutional doctrine, the Supreme Administrative Court of Lithuania and the Chief Official Ethics Commission practices.

Virginijus Kanapinskas - Mykolo Romerio universiteto Teisès fakulteto Konstitucinès ir administracinès teisès instituto lektorius, socialinių mokslų daktaras.

E. paštas: virginijuskanapinskas@yahoo.com

Virginijus Kanapinskas, Doctor of Social Sciences, Mykolas Romeris University, Faculty of Law, Institute of Constitutional and Administrative Law, lecturer.

E-mail: virginijuskanapinskas@yahoo.com

Straipsnis įteiktas redakcijai 2014 m. liepos mėn.; recenzuotas; parengtas spausdinti lapkričio mèn. 